\title{
Vietnam's New Law on the Right of Parties to Choose Applicable Law in Civil Relations Involving Foreign Elements
}

\author{
Tran Thi Thu Phuong ${ }^{1}$ \\ ${ }^{1}$ Vietnam University of Commerce, Hanoi, Vietnam \\ Correspondence: Assoc.Prof. Hoang Nguyen, Vietnam University of Commerce, Mai Dich - Cau Giay district, \\ Hanoi, Vietnam. Tel: 84-97-579-1205. E-mail: thuphuong.tran@gmail.com
}

Received: April 3, $2016 \quad$ Accepted: April 25, $2016 \quad$ Online Published: May 29, 2016
doi:10.5539/jpl.v9n4p93
URL: http://dx.doi.org/10.5539/jpl.v9n4p93

\begin{abstract}
In private international law, the right of the parties to choose law applicable has been acknowledged in most legal systems. However, the scope of this right of agreement varies according to the statutory regulations of each country. This paper clarifies the scope of right to agreement on applicable law of the parties, as well as the mechanism for controlling the application of law as agreed upon by the parties in private international law of Vietnam. This article also makes comparison with the law of some countries in the world in order to point out the differences between them and to make comments, assessments of the current statutory regulations of Vietnam on such issues.
\end{abstract}

Keywords: choice of applicable law, public order, mandatory rules, civil relations involving foreign elements

\section{Introduction}

The new Civil Code of Vietnam was adopted by the National Assembly on November 24, 2015. This Code will come into effect as from January 1, 2017 and replace Civil Code 2005. One of the contents to be revised in this new Code is the choice of applicable law of the parties to relationships involving foreign elements. Under provisions of the Civil Code 2015, a civil relation is regarded as involving foreign elements if it satisfies one of the following criteria:

- Having at least one party as foreign individual, legal entity.

- In case all the parties are Vietnamese, the relation is considered as involving foreign element when it is established or changed or terminated in a foreign country and when its subject is located in a foreign country.

For a civil relation, it is an important question to determine applicable law because such foreign element implies relationship with other legal systems. It can be the legal system of the country where each of the parties is located or registed for establishment, or where contract is executed, or where property is situated... In order to settle this question, Vietnamese law lay down several principles to determine applicable law to foreign related civil relation. As can be seen in Article 664 BLDS 2015, there are some general principles below:

- Priority is given to applicable international treaties to determine applicable law. Accordingly, the applicable law to civil relation involving foreign element is determined in compliance with the international treaties in which the Socialist Republic of Vietnam is a member or with the law of Vietnam.

- If the international treaties in which the Socialist Republic of Vietnam is a member or the law of Vietnam permits that parties have the right to make choice, then the applicable law is determined according to the choice of the parties.

- In other cases, the applicable law shall be determined as the law of the country that has the strongest ties to that civil relation.

This paper focuses on the scope of choice of applicable law of the parties and the mechanism for controlling the applicable law as agreed upon by the parties.

\section{The Right to Choose Applicable Law of the Parties}

The right to choose applicable law of the parties to foreign related civil relation is a legal institution that has 
been acknowledged in legislative systems for a long time in the world ${ }^{1}$. This right stems from the principle related to the freedom of association of the parties that has been recognised in international relations ${ }^{2}$. Accordingly, the parties have the freedom of choosing the applicable law they want to adjust the relation between them.

This principle has also been acknowledged in Vietnamese law in some limited cases. Under provisions of Civil Code 2015, the parties' choice of applicable law is acknowledged in some privities of estate and personal relationships. Specifically, if permitted by the law, the parties can have their choice of applicable law as follows: First, in the relation of ownership and of other rights to the assets in transit. Second, in contractual relationships, except for some particular cases in which the subject of the contract is real estate, concerning labour contract, consumer contract, involving a third party's legal rights and interests. Third, in connection with ex bond compensations.

Thus, basically, the Civil Code 2015 widens the sectors of relations in which the parties have choice of applicable law compared to the provisions of the Civil Code 2005. In addition to the first two circumstances, the Civil Code 2015 also adds the circumstance in which the parties' choice of law is applicable to ex bond compensation relationships.

Furthermore, the Civil Code 2015 also widens the scope of the parties' choice of applicable law in the contractual relationships between them. If the Civil Code 2005 imposed limitation on choice of law applicable to contractual relationships in terms of the parties' rights and obligations but no stipulations on other matters, such as contractual interpretation, contract implementation, legal liabilities, including assessment of damage, validity of contract, type of contract, etc. This situation may create difficulties in the actual implementation, but now with the Civil Code 2015, the scope of right can be extended to all those matters related to contractual relationships.

This new regulation has removed the contradictions between the two legal documents, namely Civil Code 2005 and Commercial Law 2005. In fact, Commercial Law recognises the rights to choose applicable law for parties in trade transactions involving foreign elements without being restricted to any particular matter of the contract. In other words, the parties are entitled to agree on choice of applicable law to every matter ensuing from this type of trade relationships. The Civil Code 2015 extends the scope of the parties' choice of applicable law in their contractual relationships, then it overcomes the contradiction between the two acting in the matter mentioned above.

The Civil Code 2015 only imposes limitation on choice of applicable law in some particular circumstances in order to protect the matters or subjects that the State should respect or protect. Specifically, with reference to immovable property, the law applicable to the transfer of right to use and other rights, the rental of property or the use of property to guarantee the fulfillment of obligations must be the law of the country where the property is situated. If related to any labour contract, consumer contract that may affect the minimal interests of employees, consumers as prescribed by the law of Vietnam, then the law of Vietnam will apply. Or in the case of the parties' change of the applicable law which affects any third party's legal interests, such change must be consented by the third party. In the sphere of ex bond compensation, the damage causing party and the damaged party have their places of residence, for individuals or places of establishment, for legal entities in the same country, the law of that country will apply.

This is a brand new regulation of the Civil Code 2015, compared with the previous one. The Civil Code 2015 extends the parties' scope of choice of applicable law in foreign related civil relations, but still ensures the legal rights and interests of the entities in disadvantage positions (such as employees, consumers), and the third parties. The Civil Code 2015 respects and protects also the regulation of Vietnamese law or foreign law relating to immovable property as fixed assets in the contractual relations between the parties and facilitates the determination of law governing the ex bond indemnity relationships between the parties when they all reside or base themselves in one country.

In the experience of many countries over the world in the area of private international law, choice of applicable law is not only acknowledged in contract but also in numerous other realms such as inheritance, marriage, family... Private international law of many countries permits parties to choose law applicable in the issues that

\footnotetext{
${ }^{1}$ Theoretically, this right has been referred to by the world's scholars such as: I. Kant, Doctrine du droit, trad. Barni, Paris 1853; A. Weiss, Traité élémentaire de droit international privé, Paris 1886; E. Gounot, Le principe de l'autonomie de la volonté en droit privé: étude critique de l'individualism juridique, Thesis Dijon, 1912;

2 I. Fetze Kamdem, "L'autonomie de la volonté dans les contrats internationaux", Les Cahiers de Droit, vol. 40, n.3, septembre 1999, pp 645-663. D. Tallon and D. Harris (dir.), Le contrat aujourd'hui: comparaison franco-anglaises, Paris, L.G.D.J, 1987; P. Nygh, Autonomy in international contract, Oxford University Press, 1999;
} 
fall within their right of choice. For the areas that do not fall within the right of choice of the parties, applicable law shall be designated by norms of conflict of laws. The law of some countries like France, Germany... differentiate the realms that the subjects have right do determine applicable law from the realms in which they don't have this right, but state should intervene, such as competition, consumer right protection, matters related to conditional lines of business such as casino, securities, etc.

In the realm of inheritance, the present trends of private international law show that inheritors' will has ever been upgraded. Swiss law on private international law permits foreigners to choose the law of the country where they are citizenships to deal with the issue of inheritance at wills (Article 90 of Switzerland's Federal Code on Private International Law 1987)3. Private international law of Belgium also permits foreigners to choose the law of the place where inheritors have citizenships or residence to deal with this issue (Article 78 of the Act on Private International Law of Belgium 2004) ${ }^{4}$. In the realm of conjugal assets, private international laws of various countries permit the parties to have choice of applicable law as Belgium (Article 49 of the Act on Private International Law of Belgium 2004), Switzerland (Article 52 of Switzerland's Federal Code on Private International Law 1987), China (Article 24 of the Law on Foreign related Civil Relations $2010^{5}$ )....

Apart from extending the area and scope of the parties' choice of law applicable in foreign related civil relations as analyzed above, the Civil Code 2015 also broadens the kinds of law the parties have right to agree on. Previously, the Civil Code 2005 restricted the parties to choose only law but not international practices. Consequently, international practices only applied in the last resort when the law of Vietnam, international treaties, or contracts between parties did not govern. This restriction has been removed. Article 666 of the Civil Code 2015 specifies that parties have the right to choose international practices in the case where the international treaties in which Vietnam is a member or Vietnamese law stipulates the parties being entitled to choose applicable law.

Through the analysis above, one can observe the innovation of Vietnamese law in permitting parties in civil relations involving foreign elements to have choice of applicable law. The innovation manifests the extension of such rights to the parties but still respects and defends the relations that the law of Vietnam deems important.

\section{The Control over the Parties' Choice of Applicable Law}

In order to make the right of choice of applicable law reality, it is obligatory that the consequences of applying foreign law, international practices must not be contrary to the basic principles of Vietnamese laws. In other words, there is a control over the parties' choise of applicable law. The Civil Code 2015 still maintains the term "basic principle of the law of Vietnam" unchanged against the stipulation of the Civil Code 2005 so as to take control over the application of foreign law or international pratices. It has become obvious that such control is effectuated when the parties have had the choice of applicable law and this law is being used to govern the relationships between them. By then, if it is found by a judge or an arbitrator that the consequences of applying foreign law, international practices are contrary to the basic principles of the law of Vietnam, that law shall not apply any more. In this case, the law of Vietnam will apply.

The basic principles of Vietnamese law are all prescribed in different acts including the Constitution and other special acts such as the Civil Code, Penal Code, Maritime Law, Business Law, Law on Marriage and Family... All these principles constitute the basis of Vietnamese legal system that maintains public order; protects, upholds and develops the good values of the Vietnamese nation. For example, Article 3 of the Civil Code 2015 expressly states that the basic principles of civil law aim to ensure the right to equality of each entity before the law; the principle of free consent in civil transaction and no violation of national interest, public interest, legal rights and interests of other people... For that reason, when the applicable law goes against the basic values protected by the law of Vietnam, that law will be repealed.

Hence, it can be observed that the control of law applicable consented by parties will only be imposed at the last step, when that law is in the process of application. However, in many countries, the control is effectuated in both pre-check and post-check steps.

In the pre-check step, foreign laws are excluded when the judge determines that some important legal norms of

\footnotetext{
${ }^{3}$ Refer to the Federal Act on Private International Law of Switzerland at: https://www.admin.ch/opc/fr/classified-compilation/19870312/, accessed on 16/2/2016

${ }^{4}$ Refer to the Act on Private International Law of Belgium at: http://reflex.raadvst-consetat.be/reflex/index.reflex?docid=87708\&lang=fr , assessed on 16/2/2016

${ }^{5}$ Refer to the Act on Private International Law of China at: http://cjcl.oxfordjournals.org/content/1/1/185.full.pdf+html, assessed on 16/2/2016
} 
his country must apply. In the laws of other countries in the world, particularly France, Belgium, Switzerland or the United States, the post-check step is conducted under certain rules namely mandatory rules or "lois de police" or "lois d'application immediate" in French ${ }^{6}$. Such mandatory rules are imposed in order to safeguard the essential interests of the country where the court is located. According to the European Union, mandatory provisions are provisions that the respect for which is regarded as crucial by a country for safeguarding its public interests, such as its political, social or economic organization, to such an extent that they are applicable to any situation falling within their scope, irrespective of the law otherwise applicable to the contract under this Regulation (Article 9 of the Regulation of the European Parliament and European Council on law applicable to contractual obligations dated, known as Rome $1^{7}$ ). China also has regulation on such mandatory rules at Article 4 of the Law on foreign related civil relations. According to this Article, if the case involve Chinesse mandatory rules, these rules will be applied immediately.

There should be distinction between mandatory rules governing relations involving foreign elements and mandatory rules applied in domestic relations. The latter ones have connotations covering the previous ones. In other words, a mandatory rule in domestic relations must not necessarily be a mandatory rule in foreign related civil relations while the last ones must be applied even in domestic relations. If a rule is mandatory in foreign related civil relations, then it will certainly be applicable to domestic relations. For instances, there are mandatory rules in the domains of intellectual property (personal rights to works), of labour (employee's rights to protection), consumer rights... Such rules are not only mandatory in domestic relationships but also mandatory at an international level, thereby often being regarded as mandatory in private international law. It can be observed that the mandatory rules in relations involving foreign element have very limited scope. All judges of the European Union in general and of France in particular have strict interpretation and applications of these mandatory rules ${ }^{8}$.

The post-check step is effectuated when foreign laws have been referred to and considered by judges to deal with cases. This post-check regulation enables the control over foreign law application to be more stringent. In the post-check step, the term "public order" or "public policy" or "ordre public" in French is inclined to be used.

If the application of the foreign law conduct to the contradiction to public order, the foreign laws shall be rejected. The term "public order" usually means covering the basic legal rules that have internationally been recognized such as anti-racism, religions, gender; the rules that constitute the foundation for the socio-politico-economic machinery of a country (non-religions political regime, for instance); important policies of a country, of an institution ${ }^{9}$. Article 6 of the Introductory Law to German Civil Code provides a way of understanding public order which covers the basic rules of German laws and fundamental rights. The fundamental rights that can be construed through trial practices of German judges are included in Articles from 1 through 19 in the Basic Laws (Grundgesetz) of the Federal Republic of Germany with the fundamental rights regarding human dignity, human equality (especially gender), other fundamental human rights as recognized by European countries $^{10}$. If the application of any foreign law obviously go against the basic rules of the German laws or against the fundamental rights, such laws will be rejected ${ }^{11}$. In European Regulation, the term public order is often used to cover the basic regulations of the Treaty establishing the European Community ${ }^{12}$.

In the same way of using mandatory rules in private international law, the use of post-check controlling mechanism is also very limited. Because when applying in this case, countries would face the problems arising

\footnotetext{
${ }^{6}$ Refer further to researches on mandatory rules or police rules: M. R. Baniassadi, "Do mandatory rules of public law limit choice of law in international commercial arbitration", Berkeley Journal of International law, vol 10, 1992; A. Barraclough và J. Waincymer, "Mandatory rules of law in international commercial arbitration", Melbourne Journal of International law, vol, 6, 2005.

${ }^{7}$ See more on the website: < http://eur-lex.europa.eu/LexUriServ/LexUriServ.do?uri=OJ:L:2008:177:0006:0016:fr:PDF>, accessed on $16 / 2 / 2016$.

${ }^{8}$ Defining police rules and applying police rules to legal precedents of French courts and European Court of Justice: Com., 28 November 2000, Civ. 1st, 6 April 1994, C.J.C.E. 23 November 1999,

${ }^{9}$ Learn more about the term "public order": G. H. Dession, "The technique of Public Order: Evolving Concepts of Criminal law", 5. Buff. L. Review, 1955-1956, pp. 20-47; R. De Lange, "The European Public Order, Constitution Principles and Fundemental Rights", Eramus Law Review, Vol. 1, No 12007

10 Refer to the Basic Law of the Federal Republic of Germany on the website: https://www.bundestag.de/blob/189762/f0568757877611b2e434039d29a1a822/loi_fondamentale-data.pdf, accessed on 16/2/2016.

${ }^{11}$ Refer to the Introductory Law to German Civil Code on the website: http://jafbase.fr/docUE/Allemagne/DIPFrench.PDF, accessed on 16/2/2016

${ }^{12}$ Refer to Case C-295/04 Manfredi (2006) ECR, I-6619, paragraph 31, therefrom the European Court stated that Articles 81, 82 of the Treaty on the establishment of the European Community in the public domain had to directly be applied by national courts.
} 
in the external relations with the country concerned. The use of public order may also affect the national image in international economic relations especially in the eyes of foreign investors. The practical applications of France have shown that French judges usually take into greatest consideration when applying public order, even in civil relations. For example, according to the judges of the French Supreme Court of Appeal, a foreign act that bans de facto marriage will not violate public order ${ }^{13}$. This act nevertheless will violate public order if children born from such marriage have French citizenship or reside in France ${ }^{14}$. In order to restrict the inapplication of foreign law, French judges and legal researchers even classify the term of public order into "ordre public interne" (internal public order) and "ordre public international" (international public order). Therefrom, the term of "international public order" is construed as an integration of the rules of justice that have been widely acknowledged to have international values such as human basic rights, human dignity, besides the norms for safeguarding and strengthening the politico-juridical regime of Republic of France ${ }^{15}$. Foreign laws will only be rejected in the case of violating international public order. Private international law of China also refers to public order in Article 5. Specifically, Article 5 of the Chinesse Law on foreign related civil relation 2010 states that foreign laws will not apply if it cause damages to the social and public interests of the People's Republic of China.

The post-check step is imposed not only to control the compliance with the basic principles of the national laws but also to control the cases in which the national legal system cannot contemplate or stipulate expressly. By then, judges will be fully able to use public order to safeguard the essential interests of society, of the country or of the international community as a whole.

\section{Concluding Remarks}

As analyzed above, it is obvious that the current provisions of the Civil Code of Vietnam essentially conform to international practices. In fact, the Civil Code 2015 of Vietnam has overcome the restrictions of the Civil Code 2005 on the freedom of choice of applicable law in relations involving foreign elements in order to enable private international law of Vietnam to be further conformable in the context of international integration as well as private international law practices in numerous countries over the world,. However, the law of Vietnam should be geared towards further broadening the parties' scope of choice to other fields such as inheritance at wills, marriage and family... In other words, the law of Vietnam should permit the parties to choose law applicable in the realms where they have the right to determine the same as from the experiences of many countries over the world. This can, on one hand, meet the need of the subjects when involved in international commercial relations and on the other hand, demonstrate the integration of the law of Vietnam in the context of international integration.

\section{References}

Baniassadi, M. R. (1992). Do mandatory rules of public law limit choice of law in international commercial arbitration. Berkeley Journal of International law, 10.

Barraclough, A., \& Waincymer, J. (2005). Mandatory rules of law in international commercial arbitration. Melbourne Journal of International law, 6.

De Lange, R. (2007) The European Public Order, Constitution Principles and Fundemental Rights. Eramus Law Review, 1(1).

Dession, G. H. (1955). The technique of Public Order: Evolving Concepts of Criminal law. 5. Buff. L. Review, $20-47$.

Fetze Kamdem, I. (1999, September). L'autonomie de la volonté dans les contrats internationaux. Les Cahiers de Droit, 40(3), 645-663. http://dx.doi.org/10.7202/043564ar

Gounot, E. (1912). Le principe de l'autonomie de la volonté en droit privé: étude critique de l'individualism juridique. Thesis Dijon.

\footnotetext{
${ }^{13}$ Refer to the judgment of the Civil Court, Supreme Court of Appeal, May 10, 2016 (Cass, civ, 1re, 10 mai 2006) on the website: http://www.legifrance.gouv.fr/affichJuriJudi.do?idTexte=JURITEXT000007051872, accessed on 16/2/2016.

${ }^{14}$ Refer to the judgment of the Civil Court, Supreme Court of Appeal, February 10, 1993 (Cass, civ, 1re, 10 février 1993) on the website: http://www.legifrance.gouv.fr/affichJuriJudi.do?idTexte=JURITEXT000007029998, accessed on 16/2/2016.

15 Refer further to the judgments of French judges: Cass. Civ. 25 mai 1948 Latour, on the website: http://www.interjurisnet.eu/html/dip/civ1_25_05_48.pdf, accessed on 7/9/2015; Cass, civ, 1re, 17 fevrier 2004 on the website: http://www.legifrance.gouv.fr/affichJuriJudi.do?idTexte=JURITEXT000007047082, accessed on 7/9/2015, Cass, civ, 1re, 17 avril 1953 , on the website: http://www.interjurisnet.eu/html/dip/civ1_17_04_1953.pdf, accessed on 16/2/2016;
} 
Kant, I. (1853). Doctrine du droit, trad. Barni, Paris.

Nygh, P. (1999). Autonomy in international contract. Oxford University Press.

Tallon, D., \& Harris, D. (dir.). (1987). Le contrat aujourd'hui: comparaison franco-anglaises. Paris, L.G.D.J.

Weiss, A. (1886). Traité élémentaire de droit international privé. Paris.

\section{Copyrights}

Copyright for this article is retained by the author(s), with first publication rights granted to the journal.

This is an open-access article distributed under the terms and conditions of the Creative Commons Attribution license (http://creativecommons.org/licenses/by/3.0/). 